\title{
Mempersiapkan Persalinan dengan Yoga Pregnancy
}

\author{
Ridha Wahyuni \\ STIKES Wiyata Husada Samarinda, Jl. Kadrie Oening G. Monalisa No.77, Kota Samarinda, Indonesia 75243 \\ *e-mail :dha.permata@gmail.com
}

\begin{abstract}
Abstrak
Salah satu perubahan psikologis pada trimester III adalah kecemasan karena proses persalinan yang semakin dekat. Samarinda memiliki 24 puskesmas dengan layanan kelas ibu hamil sebanyak $100 \%$. Namun baru 3 praktisi kesehatan yang menyelenggarakan yoga pregnancy. Pada masa kehamilan seorang ibu mengalami fase perubahan secara fisik dan psikologis. Perubahan ini dapat menyebabkan ketidaknyamanan, terutama pada trimester ketiga. Untuk mempersiapkan persalinan yang aman dan nyaman diperlukan sinergi antara olah fisik dan olah pikiran yang dapat diaplikasikan dalam latihan yoga pregnancy. Tujuan dari pengabdian ini adalah mengenalkan yoga pregnancy kepada masyarakat sebagai salah satu alternatif mendapatkan persalinan yang nyaman. Metode yang digunakan adalah memperagakan dan membimbing ibu hamil melakukan yoga pregnancy. Alat yang digunakan adalah matras yoga. Sasaran kegiatan ini adalah ibu hamil yang melakukan jalan santai di gor segiri yaitu sebanyak 10 orang. Hasil yang dicapai adalah ibu hamil melaksankan yoga kehamilan sampai tuntas dan tertarik mengikuti kembali. Kesimpulan pengabdian ini adalah untuk mendapatkan persalinan yang nyaman perlu dilakukan persiapan sedini mungkin dari masa kehamilan dengan melakukan latihan yoga pregnancy.
\end{abstract}

Kata Kunci : Fisik, Psikologis

\section{Pendahuluan}

Wanita yang sedang berada dalam masa kehamilan banyak mengalami perubahan pada dirinya, baik secara fisik maupun psikologis (Urip, 2016). Wanita hamil primigravida hampir semuanya mengalami kekhawatiran, kecemasan, dan ketakutan baik selama hamil, saat menghadapi persalinan maupun setelah persalinan. Adaptasi terhadap stres diatur oleh kapasitas hypothalamic-pituitary-adrenal (HPA) untuk mensekresikan hormon seperti kortisol. Peningkatan kadar kortisol pada masa kehamilan merupakan indikator adanya stress emosional. Hal ini mungkin akan berpengaruh terhadap lama persalinan. Yoga prenatal dan senam hamil merupaka terapi untuk menurunkan tingkat stress pada ibu hamil (Elok Saei Dewi, 2016).

Ketidaknyamanan fisik sudah dirasakan sejak awal kehamilan. Kemudian ditambah dengan bayangan mengenai proses persalinan dan bagaimana keadaan bayinya kelak setelah lahir. Bayangan-bayangan tersebut umum muncul pada ibu yang sebentar lagi menjalani persalinan, atau pada fase trimester III kehamilan (Urip, 2016).

Kecemasan ibu hamil trimester III dalam menghadapi proses persalinan salah satu masalah gangguan emosional yang sering ditemui dan menimbulkan dampak psikologis cukup serius (Salafas Eti, 2016). Walaupun kehamilan dan persalinan merupakan suatu peristiwa alamiah, namun seringkali dapat terjadi komplikasi. Salah satu upaya yang dapat dilakukan untuk mengurangi bahkan mencegah terjadinya kematian adalah melakukan persiapan persalinan. Ibu hamil diharapkan dapat mempersiapkan persalinannya dengan aman. Persiapan persalinan dapat dilakukan pada trimester III kehamilan (Mardiani, 2017).

Berlatih yoga secara teratur sepanjang kehamilan dapat mengkondisikan fisik dan mental untuk menjadi lebih kuat, kukuh tetapi luwes dan fleksibel untuk menyesuaikan diri terhadap berbagai situasi yang tidak menyenangkan saat menghadapi persalinan. Relaksasi akan menghambat peningkatan syaraf simpatetik, sehingga memicu hormon serotonin dan endofrin yang merupakan hormon untuk merelakskan tubuh. Akibatnya, terjadi penurunan detak jantung, irama nafas, tekanan darah, ketegangan otot, tingkat metabolisme, dan produksi hormon penyebab stres. Seiring dengan pengeluaran gelombang alfa pada tubuh terjadi penurunan tingkat hormon penyebab stres, maka seluruh badan mulai berfungsi pada tingkat lebih sehat dengan lebih banyak energi untuk penyembuhan (healing), penguatan (restoration), dan peremajaan (rejuvenation). Dengan demikian, ibu hamil akan merasa rileks seiring dengan menurunnya gejala kecemasan (Latiefa Rais Putri, 2014).

Sebagai Ibu kota propinsi Kalimantan Timur, Samarinda menjadi sorotan dalam kemajuan perkembangan pelayanan kebidanan. Di Samarinda namun masih sedikit yang kompeten dalam pelaksanakan Yoga Pregancy (3 Instruktur). Untuk mengenalkan Yoga Pregnancy kepada masyarakat dengan ini penulis tertarik melakukan pelayanan Yoga Pregnancy di ruang publik. 


\section{Metode}

Rancangan kegiatan pengabdian berupa praktik yoga pregnancy. Sasaran dalam kegiatan ini adalah ibu hamil yang berkunjung ke Gor Sempaja Samarinda. Responden berjumlah 20 ibu hamil. Metode yang digunakan adalah demonstrasi dan redemontrasi yoga pregnancy dengan penggunaan alat matras yoga dan handuk. dengan tahapan sebagai berikut:

a. Persiapan

1. Melakukan perizinan kepada pengelola Gor Sempaja Kota Samarinda.

2. Mencari responden dengan cara memasang spanduk dan mensosialisasikan menggunakan pengeras suara

3. Mempersipakan peralatan berupa matras yoga dilakukan oleh Pengabdi

b. Pelaksanaan

Pengabdian dilaksanakan pada tanggal 17 Februari 2019 di Gor Sempaja Kota Samarinda. Pengabdi menyebar kuesionar pengetahuan manfaat yoga pregnancy sebelum dan setelah menjelaskan manfaat yoga untuk persiapan persalinan dan Pengabdi melakukan demo yoga preganancy dan redemontrasi dilakukan oleh responden.

\section{Hasil}

a. Karakteristik Peserta

Tabel 1 Distribusi frekuensi

\begin{tabular}{|c|c|c|}
\hline Usia & $\mathrm{n}$ & $\%$ \\
\hline$<20$ tahun & 1 & 10 \\
\hline $20-35$ tahun & 9 & 90 \\
\hline$>35$ tahun & 0 & 0 \\
\hline Total & 10 & 100 \\
\hline
\end{tabular}

Berdasarkan data diatas sebagian besar peserta berusia 20-35 tahun (90\%) peserta.

Tabel 2. Tabel jumlah peserta berdasarkan jumlah persalinan

\begin{tabular}{|c|c|c|}
\hline Persalinan & $\mathrm{n}$ & $\%$ \\
\hline Primigravida & 8 & 80 \\
\hline Multigravida & 2 & 20 \\
\hline Total & 10 & 100 \\
\hline
\end{tabular}

Berdasarkan data diatas sebagian besar peserta primigravida (80\%) peserta.

Tabel 3. Tabel jumlah peserta berdasarkan keikutsertaan yoga sebelum hamil

\begin{tabular}{|c|c|c|}
\hline Persalinan & $\mathrm{n}$ & $\%$ \\
\hline Pernah & 1 & 10 \\
\hline Belum Pernah & 9 & 90 \\
\hline Total & 10 & 100 \\
\hline
\end{tabular}

Berdasarkan data diatas sebagian besar peserta belum pernah mengikuti yoga (90\%) peserta.

b. Respon Peserta

Pengabdi menilai pengetahuan peserta dengan menyebarkan kuesionar pretest dan postest. Sebelum pengabdi menjelaskan manfaat yoga pregnancy, $90 \%$ peserta belum tahu manfaat senam hamil yoga untuk persiapan persalinan. Peserta antusias melaksanakan yoga pregnancy, mengalami peningkatan pengetahuan menjadi $100 \%$ dan $60 \%$ peserta menginginkan dibuka kelas yoga di minggu berikutnya.

c. Dampak

Sebagian besar dari ibu hamil trimester III mengalami kecemasan dalam menghadapi persalinan. Saat usia kehamilan menjelang persalinan maka akan muncul pertanyaan dan bayangan apakah dapat melahirkan normal, cara mengejan, apakah akan terjadi sesuatu saat melahirkan, atau apakah bayi lahir selamat, akan semakin sering muncul dalam benak ibu hamil. Rasa nyeri pada saat persalinan sudah sejak dulu menjadi pokok pembicaraan para wanita (Hasuki, 2007).

Oleh karena itu dalam mempersiapkan kehamilan, ibu hamil tidak boleh memperhatikan kesehatan fisik saja tetapi juga harus menjaga kesehatan mental dan spiritualnya (Kuswandi, 2013). Alternatif terapi yang dibutuhkan dalam kehamilan adalah pemijatan dan terapi energi Seperti massage, acupressure, therapeutic touch dan healing touch dan mind body healing seperti imagery, meditasi/ yoga, berdoa, refleksi biofeedback (Perry et. al, 2010). 
Prenatal yoga memiliki lima cara yaitu latihan fisik yoga, pernafasan (pranayama), position (mudra), meditasi, dan deep relaksasi yang dapat digunakan untuk mendapatkan manfaat selama kehamilan sehingga dapat membantu kelancaran dalam kehamilan dan kelahiran secara alami dan membantu memastikan bayi yang sehat. Unsur pada yoga yang dikatakan dapat membantu menurunkan kecemasan adalah pada bagian relaksasi dan meditasi. Yoga selama kehamilan dapat membantu wanita fokus pada proses persalinan, bersiap untuk mentolerir nyeri,serta mengubah stres dan kecemasan menjadi energi (Priharyanti Wulandari, 2018).

Yoga dapat merendahkan tingkat hormon stress, temperatur tubuh, detak jantung dan tekanan darah. Efek relaksasi pada yoga juga mampu menstimulasi pelepasan endorphine, yang dapat meningkatkan respon saraf parasimpatis,mengakibatkan vasodilatasi pada pembuluh darah di seluruh tubuh dan uterus serta meningkatkan aliran darah uterus yang berefekmengurangi intensitas nyeri (Shindu, 2014).

Secara teoritis kecemasan akan turun jika individu mengalami relaksasi pada tubuhnya. Latihan prenatal gentle yoga adalah sebuah treatmen fisik yang ternyata juga dapat memberikan efek psikologis karena memberikan efek relaksasi pada tubuh seseorang dan mempengaruhi beberapa aspek psikologis pada seseorang yang melakukannya dikatakan dapat membantu menurunkan kecemasan (Aprilia, 2014).

Latihan yoga diberikan kepada ibu hamil sesuai dengan kondisi fisik ibu hamil. Latihan yoga dengan gerakan yang perlahan dapat dikombinasikan dengan latihan pernafasan terkontrol dan rangkaian kontraksi peregangan serta relaksasi kelompok otot. Latihan yoga dapat menstimulasi respon relaksasi baik fisik maupun psikologis, dimana respon tersebut menstimulasi aktifitas sistem saraf otonom parasimpatis nuklei rafe yang terletak diseparuh bawah pons dan di medulla, yang mengakibatkan penurunan metabolisme tubuh, denyut jantung, nadi, tekanan darah dan frekuensi pernafasan serta peningkatan serotonin sehingga tubuh menjadi rileks dan dapat meningkatkan kualitas tidur (Labeng, 2013)

Latihan yoga adalah sebuah treatment fisik yang ternyata juga dapat memberikan efek psikologis karena memberikan efek relaksasi pada tubuh seseorang dan mempengaruhi beberapa aspek psikologis pada orang yang melakukannya, sehingga dikatakan dapat membantu menurunkan kecemasan (Gupta, 2013)

Berdasarkan hasil penelitian yang dilakukan Beddoe et al (2009) :" The effects of mindfulness-based yoga during pregnancy on maternal psychological and physical distress" dalam Bonura (2014) menunjukkan efek menguntungkan dari dilakukannya yoga pada wanita hamil yaitu dapat mengurangi stres dan kecemasan. Berdasarkan penelitian yang dilakukan oleh Fauziah (2016) bahwa ibu primigravida yang melakukan prenatal yoga menunjukkan penurunan kecemasan terkait proses persalinan, menambah keyakinan dan kemampuan diri terkait persalinan, serta mengurangi keluhan fisik. Menurut Urech, et al (2010) dalam Khalajzadeh (2012) yoga memiliki efek positif pada pengurangan stres, kecemasan, gangguan yang berkaitan dengan kehamilan danmeningkatkan indeks kesehatan mental perempuan.

\section{Kesimpulan}

Untuk mendapatkan persalinan yang nyaman perlu dilakukan persiapan sedini mungkin dari masa kehamilan dengan melakukan latihan yoga pregnancy. Semakin banyak yang mengenal dan mengikuti yoga pregnancy semakin sejahtera ibu hamil di Samarinda.

\section{Saran} Puskesmas.

Diharapkan kegiatan yoga pegnancy dapat dilakukan berjadwal dan adanya pelatihan untuk bidan

\section{Daftar Pustaka}

Dinas Kesehatan Kalimantan Timur. 2017. Profil Kesehatan Kalimantan Timur Tahun 2016. Dinas Kesehatan Kalimantan Timur.

Aprilia, Y. (2014). Gintel Birt Balance. Jakarta: Gagas Media.

Bonura, K. B. (2014). Yoga Mind While Expecting : The Psychological Benefits of Prenatal Yoga Practice. international Journal of Childbirth Education.

Elok Saei Dewi, A. S. (2016). Pengaruh Kombinasi Yoga Prenatal dan Senam Hamil Terhadap Perubahan Kadar Kortisol dan Lama Persalinan Kala I. Jurnal Imiah Bidan .

Fauziah, L. (2016). Efektivitas Latihan Yoga Prenatal dalam Menurunkan Kecepamsan pada Ibu Primigavida. Bandung: Universitas Padjajaran. 
Gupta. (2013). A systematic reviewof yoga for state anxiety :Considerations for occupational therapy. Canadian Journal of Occupational Therapy.

Hasuki. (2007). Trauma kehamilan dan Pengaruhnya pada Janin. Jakarta: Diva.

Khalazjdeh, M. e. (2012). The Effect of Yoga On Anxiety Among Pregnant Woment in Second and Tried Trimester of Pregnancy. Scholars Research Library.

Labeng. (2013). Yoga Sehari-hari. Jakarta: Pustaka Bunda.

Latiefa Rais Putri, M. (2014). Efektifitas Yoga pada Primigravida Trimester III dala Menurunkan Tingkat Kecemasan Menghadapi Persalinan. Surabaya: Universitas Airlangga.

Mardiani. (2017). Sikap Ibu Hamil Trimester III tentang Persiapan Persalinan di Puskesmas Puuwatu Kota Kendari. Kendari: Politeknik Kesehatan Kemenkes Kendari.

Priharyanti Wulandari, D. R. (2018). Pengaruh Prenatal Yoga Terhadap Tingkat Kecemasan Ibu Primigravida Trimester II dan III. ejournal umm .

Salafas Eti, R. A. ( 2016). Efektifitas Hypno-EFT dan Pernafasan Yoga Dalam Menurunkan Kecemasan Ibu Hamil di BPM Ny. Sri Kustiah. Jurnal Ilmiah Kebidanan.

Shindu, P. (2014). Yoga untuk Kehamilan. Bandung: Qanit.

Urip, P. R. (2016). Efektifitas Latihan Yoga Prenatal dalam Menurunkan Kecemasan pada Ibu Primigrafida Trimester III. Bandung: Universitas Padjajaran. 